\title{
Introduction to 19 Live
}

Victoria Mills

Many of us missed the Aubrey Beardsley exhibition at Tate Britain, which ran for less than a fortnight in early March before the onset of lockdown. In this issue of 19 Live, Sasha Dovzhyk discusses Tate's handling of Beardsley, while Amelia Yeates reviews the recent 'Pre-Raphaelite Sisters' exhibition at the National Portrait Gallery, developing the focus of our inaugural number on Victorian women artists and art critics. The art critic, novelist, and philosopher, Vernon Lee, was also a playwright and committed pacifist. Sally Blackburn-Daniels examines an extraordinary performance of Lee's Ballet of the Nations: A Present-Day Morality (1915) staged at her Florentine villa, Il Palmerino, in summer 2019. Returning to Tate Britain, Blake scholar Susan Matthews discusses Tate's first major exhibition of William Blake's work since 2000. Finally, Kate Simpson, Justin Livingstone, and Adrian Wisnicki describe the development of Livingstone Online, a digital humanities project which explores the written and visual legacies of David Livingstone. As well as providing a hugely rich resource on Livingstone (and both British imperial and African history) Livingstone Online, developed over the past fifteen years, provides a model of best practice for the digitization and digital publication of travel records from the 'global south'. 